\title{
PReS-FINAL-2091: Extra-articular calcification after intra-articular corticosteroid injection
}

\author{
P Toftedal ${ }^{*}$, LA Bistrup, AE Christensen \\ From 20th Pediatric Rheumatology European Society (PReS) Congress \\ Ljubljana, Slovenia. 25-29 September 2013
}

\section{Introduction}

Intra-articular corticosteroid injection is a well established therapeutic option for treatment of juvenile idiopathic arthritis (JIA). Subcutaneous atrophy and depigmentation are well recognised adverse effects. Peri-articular calcification has been reported in radiological studies and the majority was asymptomatic.

\section{Objectives}

Two cases with pain and thickness around joints due to extra-articular calcification are reported in order to increase the awareness of this side effect.

\section{Methods}

Case report.

\section{Results}

Two adolescent girls with polyarticular JIA reported pain and swelling around the metacarpophalangeal (MCP) and interphalangeal (IP) joints without symptoms of arthritis in other joints. Both girls were treated with methotrexate and anti-TNF-alpha agents for years. Several flares of arthritis had been seen in both small and large joints. No extra-articular symptoms were reported. Both patients had been treated by several intra-articular corticosteroids injections with triamcinolone hexacetonide including the MCP and IP joints. No adverse effects had been noticed.

$\mathrm{X}$-ray of the hands showed periarticular or capsular calcification of some MCP and IP joints in both patients. MRI showed no signs of arthritis and no damage on intra-articular structures.

\section{Conclusion}

Intra-articular injection in JIA is a safe and rapidly effective treatment for synovitis. Extra-articular calcification,

\footnotetext{
Hans Christian Andersen Children's Hospital, Odense University Hospital,
} Odense, Denmark

(c) 2013 Toftedal et al.; licensee BioMed Central Ltd. This is an Open Access article distributed under the terms of the Creative Commons Attribution License (http://creativecommons.org/licenses/by/2.0), which permits unrestricted use, distribution, and reproduction in any medium, provided the original work is properly cited. The Creative Commons Public Domain Dedication waiver (http://creativecommons.org/publicdomain/zero/1.0/) applies to the data made available in this article, unless otherwise stated. clinically mimicking arthritis, is reported as an adverse event to corticosteroid injection. Risk of extra-articular side effects is probably higher in small joints.

\section{Disclosure of interest}

None declared.

Published: 5 December 2013

doi:10.1186/1546-0096-11-S2-P103

Cite this article as: Toftedal et al:: PReS-FINAL-2091: Extra-articular

calcification after intra-articular corticosteroid injection. Pediatric

Rheumatology 2013 11(Suppl 2):P103.
Submit your next manuscript to BioMed Central and take full advantage of:

- Convenient online submission

- Thorough peer review

- No space constraints or color figure charges

- Immediate publication on acceptance

- Inclusion in PubMed, CAS, Scopus and Google Scholar

- Research which is freely available for redistribution 